\title{
UJI BEBERAPA FORMULA INOKULUM TERHADAP PRODUKSI TUBUH BUAH JAMUR TIRAM PUTIH (Pleurotus ostreatus (Jacq.) P.Kummer.)
}

\section{The study of test for several inoculum formulas on the production of white oyster mushroom body (Pleurotus ostreatus (Jacq.) P.Kummer.)}

\author{
Dana Sulistia*, Umrah, dan I Nengah Suwastika \\ Jurusan Biologi Fakultas Matematika dan IImu Pengetahuan Alam Universitas Tadulako Tondo \\ Palu, Sulawesi Tengah 94118
}

Keywords:

Inoculum, White

Oyster Mushroom,

Fruit Body Production.
Kata Kunci:

Inokulum, Jamur Tiram Putih, Produksi tubuh buah.

\begin{abstract}
The study of test for several inoculum formulas on the production of white oyster mushroom body (Pleurotus ostreatus (Jacq.) P.Kummer.) conducted from April to September 2018 at Biotechnology laboratory, Department of Biology, Faculty of Mathematics and Natural Sciences, Tadulako University. This study were aimed to determine whether the treatment of the inoculum formula tested on the production medium can form the white oyster mushroom fruit body and to find out which inoculum formula can form the optimum fruit body in the production medium. This study was conducted by Randomized Complete Design (RAL) consisted of 4 treatments and four replications, $I_{1}\left(100 \%\right.$ corn seeds), $I_{2}$ (50\%: $\left.23 \%: 27 \%\right), I_{3}(50 \%: 17 \%$ : $33 \%)$ dan $\mathrm{I}_{4}(95 \%: 5 \%)$. The results showed that I 3 was the best inoculum for the growth of the white oyster mushroom fruit body compared to the other inoculums which were characterized by a wide mushroom hood, the length was long and the weight of fresh mushroom was high. The inoculum formula and the best dosage for body production of white oyster mushroom are found in treatment 13 ( $50 \%$ sawdust $+17 \%$ corn flour $+33 \%$ bran $)$.
\end{abstract}

\begin{abstract}
ABSTRAK
Uji beberapa formula inokulum terhadap produksi tubuh buah jamur tiram putih (Pleurotus ostreatus (Jacq.) P.Kummer.) dilaksanakan pada bulan April sampai September 2018 di laboratorium Bioteknologi Jurusan Biologi Fakultas Matematika dan IImu Pengetahuan Alam Universitas Tadulako.Penelitian bertujuan untuk mengetahui apakah perlakuan formula inokulum yang diuji pada medium produksi dapat membentuk tubuh buah jamur tiram putih dan untuk mengetahui formula inokulum mana dapat membentuk tubuh buah yang optimum pada medium produksi. Penelitian dilaksanakan dengan metode Rancangan Acak Lengkap (RAL) yang terdiri dari 4 perlakuan dan empat kali ulangan, $I_{1}$ (biji jagung 100\%), $I_{2}(50 \%: 23 \%$ : $27 \%), I_{3}(50 \%: 17 \%: 33 \%)$ dan $I_{4}(95 \%: 5 \%)$. Hasil penelitian menunjukan $\mathrm{I}_{3}$ merupakan inokulum yang terbaik untuk pertumbuhan tubuh buah jamur tiram putih dibandingakan dengan inokulum lainnya yang ditandai dengan tudung jamur lebar, tunkainya panjang dan berat segar jamur tinggi. Formula inokulum dan dosis yang terbaik untuk produksi tubuhbuah jamur tiram putih terdapat pada perlakuan $I_{3}(50 \%$ serbuk gergaji $+17 \%$ tepung jagung $+33 \%$ bekatul).
\end{abstract}

"Corresponding Author : danasulistia@gmail.com 


\section{PENDAHULUAN}

Jamur tiram putih (Pleurotus ostreatus (Jacq.) P.Kummer.) adalah salah satu produk holtikultura yang dapat dikembangkan sebagai sumber gizi masyarakat dan berkhasiat terhadap kesehatan. Protein nabati yang terdapat dalam jamur tiram hampir sebanding dengan protein hewani yang terdapat pada daging sapi serta memiliki kandungan lemak yang rendah (Masyura, dkk 2016).

Masyarakatsaat ini, lebih cenderung mengkomsumsi daging sapi guna memenuhi kebutuhan protein tubuh, akan tetapi kandungan gizi pada daging dapat menimbulkan penyakit karena tingginya kandungan kolestrol mencapai $50 \mathrm{mg}$ dan lemak 2,8 $\mathrm{g}$ sedangkan kandungan proteinnya 23,3 g per $100 \mathrm{~g}$ (Williams, 2007). Alternatif pengganti yang dapat digunakan untuk sumber protein guna memenuhi kebutuhan tubuh ialah jamur tiram putih (Pleorotus ostreatus). Kandungan protein yang terdapat pada jamur tiram, yakni sekitar 30,4\% setiap 100 $\mathrm{g}$ berat jamur tiram (Sagala, dkk 2015). Menurut Hendritomo (2010), protein jamur tiram yaitu $30-35 \%$, karbohidrat sebanyak $50 \%$,kandungan serat jamur tiram $7,4 \%$,dan 0,1\% lemak, $1 \%$ mineral (Tewari, 1986).

Budidaya jamur tiram putih dapat dilakukan dengan cara menggambil bagian dari tangkai tudung jamur tiram yang telah dewasa, kemudian ditumbuhkan pada media PSA (Potato Sukrosa Agar) yang selanjutnya digunakan sebagai Inokulum. Inokulum adalah sekumpulan hifa yang ditumbuhkan pada media untuk mendukung pertumbuhan tubuh buah dan proses perbanyakan jamur (Maulidina, dkk 2015). Sedangkan menurut Sinaga (2000), bahwa inokulum adalah jenis jamur yang dibudidayakan dengan cara sederhana,dengan kriteria dalam keadaan steril. Pemilihan benih dan media yang baik sangat berpengaruh pada proses pertumbuhan jamur.

Faktor yang mempengaruhi berhasil tidanya produksi jamur tiram adalah media inokulum yang digunakan sebagai media tanam inokulum yang mana diantaranya dapat berupa biji-bijian atau media berbahan lignoselulosa sehingga menyebabkan miselum dan tubuh buah dapat tumbuh dengan cepat (Sumarsih, 2015). Sedangkan menurut Suryani dan Carolina (2017), bahwa miselium dapat tumbuh pada pada berbagai bahan yang mengandung karbohidrat yang diperoleh dari biji jagung, tepung jagung dan ampas sagu. Jagung sendiri mengandung karbohidrat $(58 \%)$, protein $(27 \%)$, lemak $(3,79 \%)$, serat $(11,5 \%)$, abu $(9,3 \%)$ dan kalori (265 kal) (Cahaya dkk, 1999). Tepung jagung mengandung kadar protein terlarut antara $1,30 \%$ sampai $2,51 \%$, amilosa 26,9 sampai $35,9 \%$ dan kadar air 7,4 sampai 9,27\% (Corsetti dan Settani, 2007) ampas 
sagu mengandung karbohidrat, nitrogen, Corganik dan ligin yang dapat memicu pertumbuhan miselium.

Jamur tiram putih adalah jamur yang tumbuh pada media kayu yang lapuk yang bersifat sebagai pengurai pada tumbuhan residu (Zadrazil and Kurtzman, 1981). Jamur ini termaksud kelas Basidomycetes yang banyak di temukan pada daerah yang beriklim tropis dan sub tropis karena mudah diolah secara buatan (Maziero et all, 1992). Jamur memperoleh makanannya dengan cara saprofit yaitu dengan mengkonsumsi bahan-bahan organik dari hewan atau tumbuhan yang telah mati, pada proses ini fungi melepaskan enzim ke lingkungan, sehingga molekul makanan diubah menjadi lebih sederhana dan nutrisinya dapat diserap ke dalam sel (Moore, 1982). Enzim yang berperan yaitu enzim ligninolitik yang berfungsimendegradasi lignoselulosa yang terdapat pada kayu kemudian merubahnyamenjadi sumber nutrisi, yang diperlukan dalam proses pertumbuhannya (Arief, 2008). Menurut Gunawan (2004), secara umum Basidomycetes memiliki bentuk tubuh buah yang terdiri dari payung atau tudung (pileus), lamela (gill), tangkai (stipe), cincin (annulus), volva, sisik (scale) dan kortina (cortina).

Media tumbuh jamur tiram putih dapat berupa ampas tebu (Sutarman, 2012), jerami padi (Wahidah, dkk 2008), gandumjerami (Justo et al., 1999)serabut kelapa sawit (Iswahyudi, dkk 2017), ampas sagu (Sagadji, dkk 2008), serbuk gergaji. Akan tetapi petani jamur biasanya menambahkan bekatul dan kapur sebagai penambahan nutrisanya jamur tiram putih agar tubuh buah yang dihasilkan besar.

Bekatul adalah lapisan luar beras yang pecah pada saat pengililngan (Wahyuningtyas, 2014). Sedangkan menurut Kurniawati (2017), bekatul merupakan hasil sampingan padi yang telah disaring yang telah dipisahkan dari sekam atau kulit luar gabah yang berwarna coklat muda. Bekatul memiliki kandungan gizi yaitu protein $(13,11-17,19 \%)$, lemak $(2,52$ $5,05 \%)$, serat kasar $(370,91-387,3 \%)$, kalori dan vitamin B1.

Bekatul berperan dalam proses pertumbuhan dan perkembangan miselium serta pemicu pertumbuhan tubuh buah. Hal ini disebabkan karena bekatul kaya akan vitamin B kompleks, sumber nutrisi, karbohidrat, karbon dan sumber nitrogen (Soenanto, 2000). Bekatul juga mengandung mineral yang berfungsi sebagai antioksidan sedangkan kandungan karbohidratnya berupa selulosa, hemiselulosa dan pati (Kurniawati, 2017).

Serbuk gergaji kayu merupakan bahan utama yang digunakan sebagai media tumbuh dalam memproduksi jamur (Sunarmi dan Saparinto, 2010). Hal ini di karenakan serbuk gergaji kayu mengandung selulosa, hemiselulosa dan 
lignin yang dapat dimanfaatkan jamur sebagai sumber karbon dalam media tumbuhnya Suriawiria (2002). Jamur tiram memerlukan media tumbuh yang mengandung unsur karbon dalam jumlah yang banyak dalam bentuk polisakarida, Nitrat, yang akan diubah menjadi protein (Djarijah dan Nunung, 2009).

Jagung (Zea mays L) adalah jenis rerumputan dan termasuk tanaman semusim. Komposisi kimia yang terdapat pada jagung yaitu kadar lemak (33\%), protein $(18.4 \%)$ dan mineral $(10.5 \%)$. Kulit ari yang terdapat pada jagung mengandung karbohidrat yang tinggi yaitu $86.7 \%$, pati $(87.6 \%)$, protein $(8 \%)$ dan kadar lemak (0.8\%) (Suarni dan Widowati 2007). Sedangkan tepung jagung sendiri merupakan butiran butiran halus yang berasal dari endosperma yang telah dihancurkan yang masih memiliki kadar protein terlarut antara $1,30 \%$ sampai $2,51 \%$, amilosa 26,9 sampai $35,9 \%$ dan kadar air 7,4 sampai $9,27 \%$ (Corsetti dan Settani, 2007).

Limbah sagu adalah hasil dari pohon sagu yang telah mengalami proses penggilingan yang telah terpisah antara pati dan ampas. Ampas sagu sendiri masih mengandung selulosa $23 \%$, hemiselulosa $8,19 \%$ lignin $6,3 \%$ dan pati $58 \%$.

Kapur (CaCO3) berfungsi untuk mengatur tingkat keasaman $(\mathrm{pH})$ pada media tumbuh, kapur memiliki unsur karbon dan kalsium yang berfungsi untuk mempercepat pertumbuhan miselium sehingga dapat mencengah kontaminasi (Nurmianti, dkk 2016).

\section{BAHAN DAN METODE}

Penelitian ini dilaksanakan pada bulan April 2018 sampai Oktober 2018, bertempat di Laboratorium Bioteknologi Jurusan Biologi Fakultas Matematika dan IImu Pengetahuan Alam Universitas Tadulako sedangkan pada Analisis Proteinnya bertempat di Laboratorium Kimia Jurusan Kimia Fakultas Matematika dan IImu Pengetahuan Alam Universitas Tadulako.

\section{Bahan dan Alat}

Alat yang digunakan dalam penelitian ini adalah alat tulis menulis, kamera, pisau, cawan petri, bunsen, tabung reaksi, gelas ukur $1000 \mathrm{ml}$, laminar air flow (LAF), erlenmeyer, oven, botol media,neraca analitik,hotpate, autoklaf, rak tabung, spatula, timbangan, ayakan kawat ukuran $0,05 \mathrm{~mm}$ dan kalkulator.

Bahan yang digunakan dalam penelitian ini adalah sumber inokulum jamur tiram putih, bekatul, kapur $\left(\mathrm{CaCO}_{3}\right)$, akuades, PSA (Potato Sukrosa Agar), cincin baglog, plastik PP (Polypropilen) ukuran $30 \mathrm{~cm} \times 18$ $\mathrm{cm}$ dengan ketebalan $0,6 \mathrm{~cm}$ serbuk gergaji di ambil di tempat penggeregajian kayu didaerah Tondo, bekatul, ampas sagu, kapur, karet gelang, penutup plastik 
lembaran kertas ukuran $10 \mathrm{~cm}$ x $10 \mathrm{~cm}$, alkohol, label dan tisue

\section{Prosedur Penelitian}

Penelitian ini didesain dalam Rancangan Acak Lengkap (RAL), terdiri dari Empat perlakuan dan Empat kali pengulangan, susunan perlakuan sebagai berikut:

\section{Formula Inokulum Pada Media Botol :}

$\mathrm{I}_{1}=$ Biji jagung $100 \%$

$\mathrm{I}_{2}=(50 \%$ serbuk gergaji $+23 \%$ tepung jagung $+27 \%$ bekatul)

$\mathrm{I}_{3}=(50 \%$ serbuk gergaji $+17 \%$ tepung jagung $+33 \%$ bekatul)

$\mathrm{I}_{4}=(95 \%$ serbuk gergaji $+5 \%$ ampas sagu $)$

\section{Pengumpulan bahan}

Pengambilan sumber inokulum jamur tiram putih, bekatul, kapur diperoleh dari CV. Jamur sumber urip Sulawesi Tengah, sedangkan serbuk geregaji diperoleh dari tempat penggeregajian kayu didaerah Tondo.

\section{Sterilisasi alat dan bahan}

Seluruh peralatan alat kaca yang digunakan pada pada penelitian ini, terlebih dahulu dicuci denagan deterjen, yang berfungsi untuk membunuh mikroorganisme yang melekat pada alat, lalu seluruh alat kaca tersebut dibungkus dengan menggunakan kertas bekas, kemudian dimasukkan kedalam plastik tahan panas. Hal ini bertujuan agar alat kaca yang digunakan tidak mudah pecah. Selanjutnya seluruh alat kaca, medium dan aquades disterilisasi dengan menggunakan autoklaf pada suhu $121^{\circ} \mathrm{C}$ dengan tekanan $2 \mathrm{~atm}$ selama 15 menit (Cappucino and sherman, 2008).

\section{Pembuatan Media Potato Sukrosa Agar} (PSA)

Langkah awal pembuatan media PSA yaitu dengan menyiapkan bahan berupa kentang (200 g), agar (20 g), gula (20 g) dan akuades $1000 \mathrm{ml}$. Kentang yang digunakan terlebih dahulu dikupas dan dicuci menggunakan air besih kemudian dipotong kecil-kecil bentuk dadu, kemudian merebus kentang menggunakan 1000 ml akuades hingga mendidih (kentang terasa empuk) dengan menggunakan hot plate lalu ekstrak kentang disaring untuk dipisahkan untuk mendapatkan ekstrak sarinya. Selanjutnya larutan ditambahkan gula dan agar diaduk hingga homogen, selanjutnya disterilkan menggunakan autoklaf dengan suhu $121^{\circ} \mathrm{C}$ selama 15 menit kemudian didinginkan pada suhu kamar dan media PSA dituang pada cawan petri steril dan dibiarkan hingga padat.

\section{Pembuatan Formula Inokulum dalam botol}

a. Inokulum yang digunakan terdiri dari biji jagung, serbuk gergaji, bekatul, tepung jagung dan ampas sagu. Serbuk gergaji dan ampas saguyang digunakan terlebih dahulu diayak menggunakan pengayakan besi ukuran 0,04 $\mathrm{mm}$ 
sedangkan biji jagung yang digunakan disortir (biji jagung yang ukurannya besar dan sehat) untuk menetukankualitas terbaik.

b. Penimbangan

Semua formula inokulum yang digunakan ditimbang sesuai dengan konsentrasi perlakuan yang digunakan dengan menggunakan satuan gram.

c. Pencampuran

Pencampuran dilakukan dengan cara mencampur serbuk gergaji, tepung jagung, bekatul,kemudian menambahkan air pada media sebanyak $350 \mathrm{ml}$ hingga rata, kemudian menimbang semua media sesuai takaran $\left(I_{2}, I_{3}, I_{4}\right)$ dengan satuan gram. Biji jagung $\left(I_{1}\right)$ yang digunakan direbus selama 60 menit kemudian diginkan selama 2 jam.

d. Pengomposan

Pengomposan dilakukan dengan cara menutup media $\left(I_{2}, I_{3}, I_{4}\right)$ dengan menggunakan karung selama $1 \times 24$ jam.

e. Pengisian pada media botol

Media yang dimasukkan kedalam botol sebanyak $100 \mathrm{~g}$ dengan tinggi setiap media pada botol seragam. Selanjutnya pada bagian atas botol ditutup dengan plastik kemudian diikat dengan karet gelang.

f. Sterilisasi media

Sterilisasi botol dilakukan de2engan cara memasukkan media pada autoklaf dengan suhu $121^{\circ} \mathrm{C}$ selama 15 menit.
Selanjutnya diamkan sampai dingin sebelum di tambahkan inokulum.

\section{Persiapan media tanam pada baglog}

a. Pengayakan

Serbuk gergaji sebelum dicampur dengan bahan-bahan yang lainnyaterlebih dahulu dilakukan pengayakan.Pengayakan dilakukan untuk menyeragamkan serbuk gergaji yang diinginkan. Hal ini dilakukan agar pencampuran serbuk gergaji dengan bahan-bahan lainya merata, ayakan yang digunakan berukuran $0,05 \mathrm{~mm}$.

b. Pencampuran bahan

Bahan yang digunakan yaitu serbuk gergaji yang telah di timbang dengan berat $477 \mathrm{~g}$, bekatul yang sudah ditimbang denganberat $118 \mathrm{~g}$ dan kapur $\left(\mathrm{CaCO}_{3}\right)$ yang telah ditimbang dengan menggunakan neraca analitik dengan berat $5 \mathrm{~g}$. Semua bahan kemudian dicampur dengan menggunakan tangan hingga merata.

c. Pengomposan

Pengomposan dilakukan selama $1 \times 24$ jam dengan cara semua bahan campuran serbuk gergaji di kumpul menjadi satu kemudian menutupnya secara rapat dengan menggunakan terpal. Pengomposan bertujuan untuk mengurai senyawa-senyawa kompleks yang ada didalam bahan dengan bantuan mikroba sehingga di peroleh senyawa-senyawa yang lebih sederhana. 
d. Sterilisasi baglog

Sterilisasi baglog dilakukan dengan cara memasukkan semua baglog kedalam autoklafdengan suhu $121^{\circ} \mathrm{C}$ selama 20 menit. Hal ini bertujuan untuk mematikan mikroorganisme lain yang menjadi kontaminan untuk pertumbuhan jamur tiram putih. Baglog (media tanam) yang sudah di sterilisasi dengan menggunakan autoklaf selanjutnya didinginkan selama $1 \times 24$ jam.

e. Inokulasi

Inokulasi dilakukan dengan menyemprotan alkohol pada bagian tangan kemudian spatula yang digunakan terlebih dahulu di rendam dengan menggunakan alkohol.Inokulasi dilakukan dengan membuka karet gelang plastik, kemudian bibit inokulum $\left(I_{1}, I_{2}, I_{3}\right.$, $\mathrm{I}_{4}$ ), dimasukkan kedalam media pada bagian tengah sebanyak $5 \mathrm{~g}$ kemudian ditambahkan cincin baglog ditutup dengan kertas.

f. Inkubasi

Inkubasi dilakukan dengan cara menyimpan semua baglog di kumbung jamur dengan posisi horizontal dan di biarkan sampai tumbuh miselium jamur tiram putih.

g. Pemeliharaan

Pemeliharaan dilakukan dengan cara menjaga kestabilan suhu ruang dan kelembapan udara, hal ini dilakukan dengan cara mengukur kelembapan udara dengan menggunakan hygrometer sedangkan untuk mengukur suhu ruangan dengan menggunakan termometer. Meselia yang sudah penuh didalam baglog kemudian dibuka dengan cara melepaskan cincin baglog. Pemanenan dilakukan setelah jamur tiram berumur 6hari. Pemanenan dilakukan dengan cara menyemprot jamur dalam satu rumpun pada bagian meselia dengan menggunakan air sehinga jamur terlepas dari baglog.

h. Data yang diperoleh dianalisis dengan anlisis ANOVA menggunakan program software SPSS (Statistical Package for the Social Sciences) dan software Statsaft untuk membuat gambar grafik pengamatan.

\section{HASIL}

\section{Waktu munculnya pinhead (Hari)}

Waktu munculnya pinhead pada media baglog dengan komposisi baglog $600 \mathrm{~g}$ membutuhkan waktu yang berbeda-beda dari ke-4 perlakuan.

Berdasarkan gambar diagram 1.standar eror dari ke empat perlakuan yang paling lambat yaitu pada perlakuan $\mathrm{I}_{4}$ dengan waktu rata-rata yang dibutuhkan 46 hari sedangkan pada media baglog yang tercepat pada perlakuan $I_{1}$ (memakai biji jagung) dengan waktu yang dibutuhkan 38 hari. Secara statistik menunjukan tidak 
berpengaruh nyata dari ke empat perlakuan.

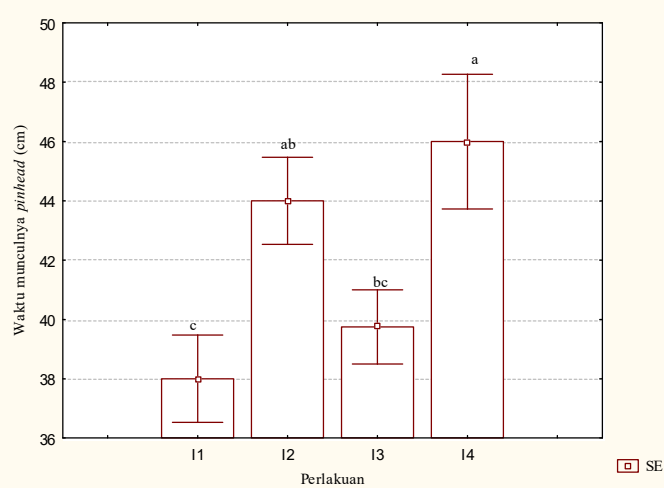

Gambar 1. Diagram waktu munculnya pinhead terhadap semua perlakuan.

\section{Jumlah rata-rata pinhead/baglog}

Perhitungan jumlah rata-rata pinhead/baglog dari ke-4 perlakuan menunjukan jumlah pinhead yang berbeda, perhitungan jumlah rata-rata pinhed dilakuan dari hari pertama sampai hari ketiga hingga jamur berubah menjadi tubuh buah pada hari ke-6. (Gambar 3).

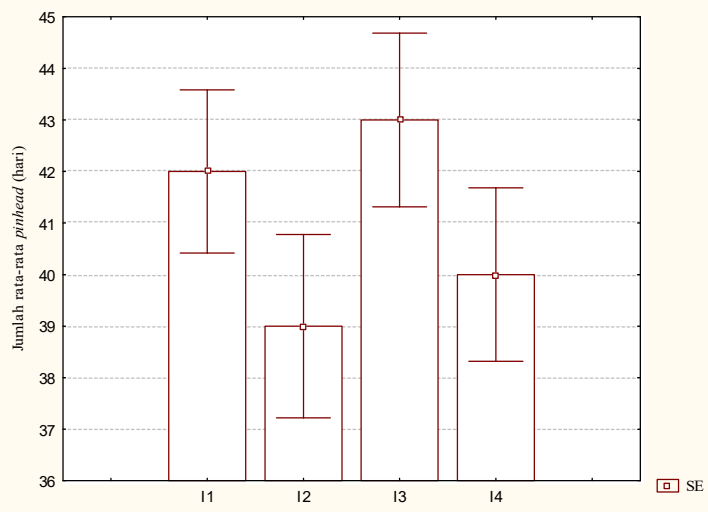

Gambar 2. Diagram jumlah rata-rata pinhead terhadap semua perlakuan.
Berdasarkan gambar diagram 2standar eror dari keempat perlakuan $I_{3}$ menunjukan jumlah rata-rata pinhed yang paling tinggi dengan jumlah rata-rata pinhead 43 buah sedangkan jumlah ratarata pinhed terendah pada perlakuan $I_{2}$ dengan jumlah pinhed 39 buah. Secara statistik menunjukan tidak berpengaruh nyata jumlah rata-rata pinhed pada setiap perlakuan yang ditumbuhkan pada media baglog.

\section{Rata-rata diameter tudung jamur tiram}

Pengamatan rata-rata diameter tudung jamur dari ke-4 perlakuan dilakukan dengan cara mengukur diameter tudung yang dihasilkan jamur tiram dalam satu kali panen yaitu yang berumur 6 hari dengan komposisi media tanam $600 \mathrm{~g}$.

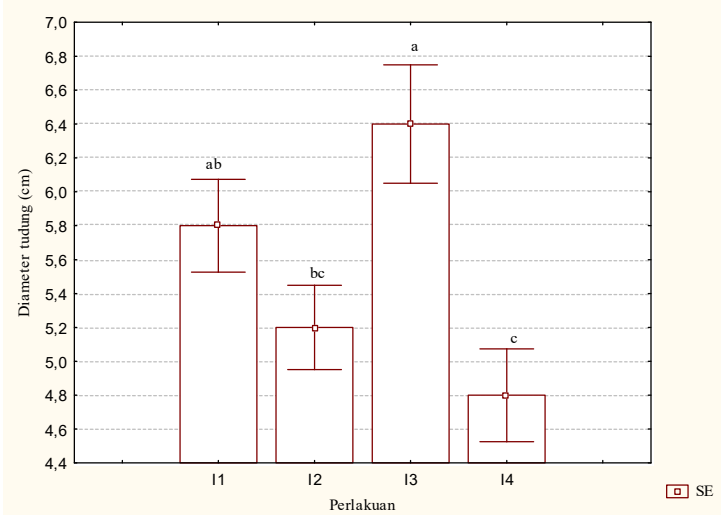

Gambar 3. Diagram jumlah rata-rata diameter semua perlakuan.

Berdasarkan gambar diagram 3 standar eror pada perlakuan menunjukan rata-rata diameter tudung yang paling besar terdapat pada perlakuan $I_{3}$ dengan rata-rata 
diameter tudung 6,4 cm sedangkan jumlah rata-rata pinhed terendah pada perlakuan $\mathrm{I}_{4}$ dengan jumlah diameter tudung $4,8 \mathrm{~cm}$. Secara statistik menunjukan tidak berpengaruh nyata jumlah diameter tudung pada setiap perlakuan yang ditumbuhkan pada media tanam.

\section{Rata-rata panjang tangkai tudung jamur tiram putih}

Pengukuran rata-rata panjang tangkai dilakukan dengan cara menggunakan mistar dengan satuan sentimeter, pengukuran panjang tangkai pada jamur diukur secara vertikal mulai dari ujung diameter jamur hingga pangkal jamur yaitu pada saat pemanenan dekat dengan baglog.

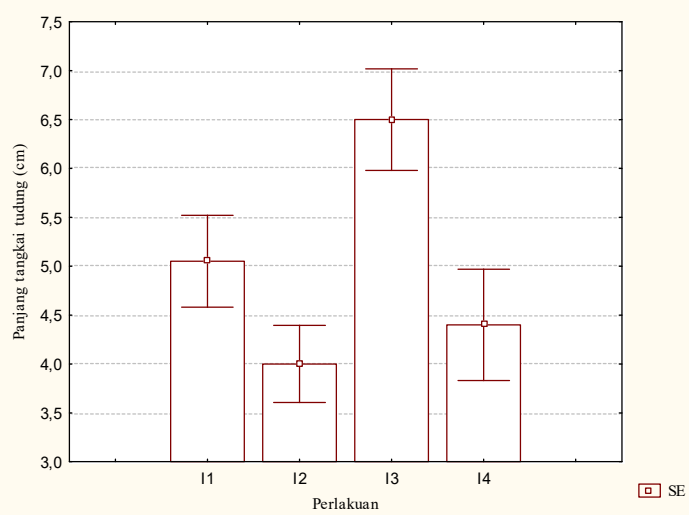

Gambar 4 Diagram rata-rata panjang tangkai tudungterhadap semua perlakuan.

Berdasarkan gambar diagram 4 standar eror pada perlakuan menunjukan rata-rata panjang tangkai tudung yang paling besar terdapat pada perlakuan $I_{3}$ dengan rata-rata panjang diameter tudung $6,5 \mathrm{~cm}$ sedangkan jumlah rata-rata panjang tangkai tudung yang paling kecil terdapat pada perlakuan $\mathrm{I}_{4}$ dengan rata-rata panjang tangkai tudung 4,3 cm. Secara statistik menunjukan tidak berpengaruh nyata jumlah rata-rata panjang tangkai tudung pada setiap perlakuan yang ditumbuhkan pada media tanam.

\section{Jumlah tubuh buah jamur tiram putih}

Jumlah tubuh buah jamur dilakukan dengan cara menghitung jumlah keseluruhan jumlah tudung dalam satu rumpun jamur dari hasil panen.

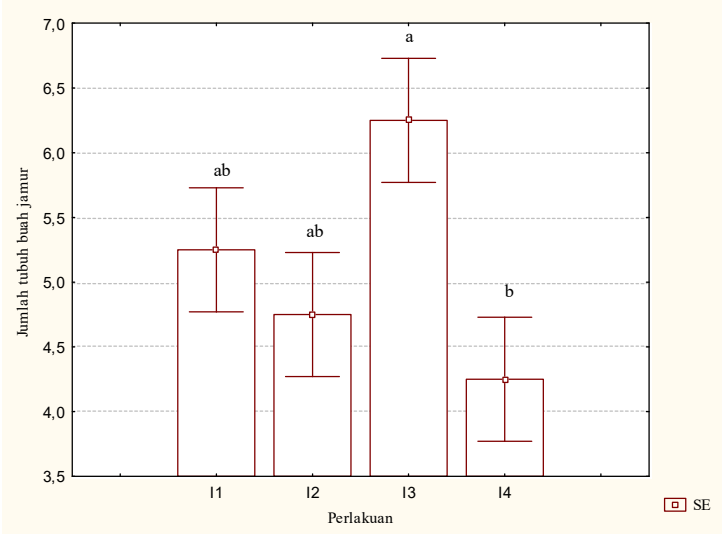

Gambar 5 Diagram jumlah diameter tudung terhadap semua perlakuan.

Berdasarkan gambar diagram 5 standar eror menunjukan jumlah tubuh buah jamur dari keempat perlakuan $\mathrm{I}_{3}$ menunjukan jumlah tubuh terbanyak yaitu 6,25 buah sedangkan tubuh buah yang paling sedikit terdapat pada perlakuan $\mathrm{I}_{4}$ yaitu 4,25 buah. Secara statistik menunjukan tidak berpengaruh nyata jumlah tubuh buah jamur tiram putih pada setiap 
perlakuan yang ditumbuhkan pada media tanam.

\section{Berat biomassa tubuh buah segar}

Pengamatan pada berat biomassa tubuh buah segar dilakukan dengan cara menimbang berat jamur yang baru dipanen dengan menggunakan timbangan neraca analitik.

Berdasarkan gambar diagram 6 standar eror menunjukan berat biomassa tubuh buah segar $I_{1} I_{2}, I_{3}$ dan $I_{4}$. Dari keempat perlakuan yang paling besar terdapat pada perlakuan $I_{3}$ dengan berat biomassa $73,5 \mathrm{~g}$ sedangkan berat biomassa yang paling kecil terdapat pada perlakuan $\mathrm{I}_{4}$ dengan berat biomassa 34,3 g. Secara statistik menunjukan tidak berpengaruh nyata jumlah rata-rata panjang tangkai tudung pada setiap perlakuan yang ditusmbuhkan pada media tanam.
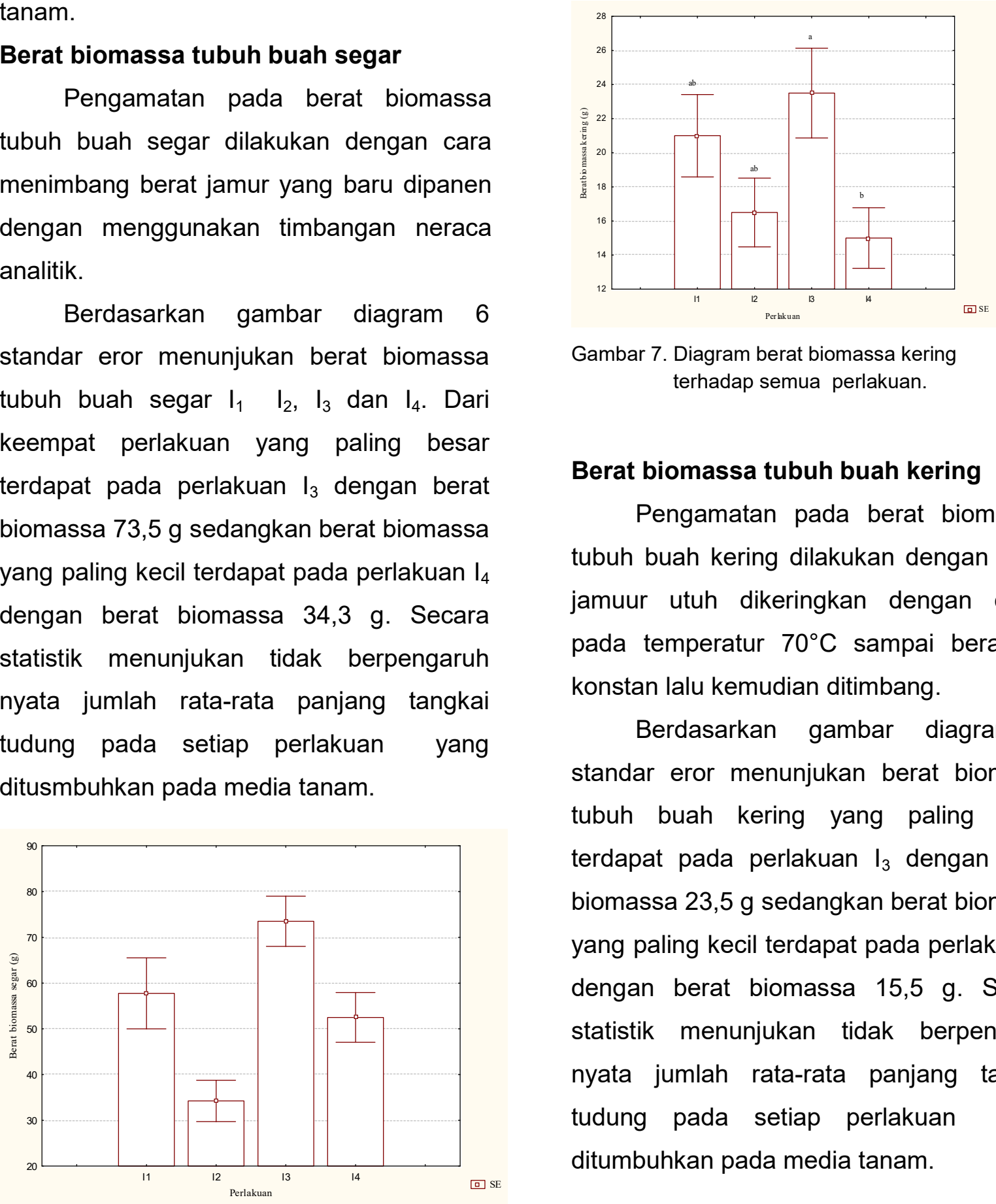

Gambar 7. Diagram berat biomassa kering terhadap semua perlakuan.

\section{Berat biomassa tubuh buah kering}

Pengamatan pada berat biomassa tubuh buah kering dilakukan dengan cara jamuur utuh dikeringkan dengan oven pada temperatur $70^{\circ} \mathrm{C}$ sampai beratnya konstan lalu kemudian ditimbang.

Berdasarkan gambar diagram 7 standar eror menunjukan berat biomassa tubuh buah kering yang paling besar terdapat pada perlakuan $\mathrm{I}_{3}$ dengan berat biomassa 23,5 g sedangkan berat biomassa yang paling kecil terdapat pada perlakuan $\mathrm{I}_{4}$ dengan berat biomassa 15,5 g. Secara statistik menunjukan tidak berpengaruh nyata jumlah rata-rata panjang tangkai tudung pada setiap perlakuan yang ditumbuhkan pada media tanam.

Gambar 6. Diagram berat biomassa segar terhadap semua perlakuan. 


\section{PEMBAHASAN}

Inokulum adalah sekumpulan hifa atau miselium yang ditumbuhkan pada suatu media untuk mendukung pertumbuhan tubuh buah dan proses perbayakan jamur (Maulidina dkk., 2015). Pada penelitian ini, formula inokulum yang digunakan yaitu $\mathrm{I}_{1}$ (biji jagung 100\%), $\mathrm{I}_{2}$ (50\% serbuk gergaji $+23 \%$ tepung jagung $+27 \%$ bekatul), $I_{3}(50 \%$ serbuk gergaji + $17 \%$ tepung jagung $+33 \%$ bekatul) dan $\mathrm{I}_{4}$ (95\% serbuk gergaji $+5 \%$ ampas sagu).

Hasil penelitian menunjukan bahwa inokulum yang digunakan dapat tumbuh pada setiap perlakuan, meskipun terdapat perbedaan waktu munculnya pinhead memenuhi media baglog. Waktu yang dibutuhkan pinhead untuk tumbuh dihitung mulai penanaman inokulum ke dalam media baglog. Pertumbuhan yang paling cepat adalah pada perlakuan $\mathrm{I}_{1}$ (Biji jagung) dengan rata-rata waktu yang dibutuhkan untuk tumbuh yaitu 38 hari, sedangkan $\mathrm{I}_{4}$ (95\% serbuk gergaji $+5 \%$ ampas sagu) dengan pertumbuhan rata-rata 46 hari. Perlakuan yang paling lambat pinhead tumbuh yaitu pada $\mathrm{I}_{4}$. Hal ini menunjukan bahwa ampas sagu yang diberikan bepengaruh pada lamanya pinhead untuk tumbuh. Hal ini disebabkan karena ampas pati sagu mengandung amilopektin $73 \%$ dan amilosa 27\% (Swinkels, 1985), sedangkan menurut Rosmawati (2013), amilosa pada ampas pati sagu mempunyai sifat yang keras sedangkan amilopektin bersifat lengket sehingga sulit untuk di degradasi oleh jamur. Selain itu adanya faktor lingkungan yang berpengaruh terhadap munculnya pinhead yang terdiri dari suhu dan kelembaban. Suhu yang optimal untuk pertumbuhan pinhead adalah $16^{\circ} \mathrm{C}-22^{\circ} \mathrm{C}$ dengan kelembaban 95\%-98\% (Maulana, 2012).

Perhitungan jumlah rata-rata pinhead/baglog dari 4 perlakuan dihitung selama 3 hari. Berdasarkan gambar 2 menunjukan jumlah rata-rata pinhed yang paling tinggi terdapat pada perlakuan $\mathrm{I}_{3}$ (50\% serbuk gergaji $+17 \%$ tepung jagung $+33 \%$ bekatul) dengan jumlah rata-rata 43 buah sedangkan jumlah rata-rata pinhed terendah pada perlakuan $\mathrm{I}_{2}(50 \%$ serbuk gergaji $+23 \%$ tepung jagung $+27 \%$ bekatul), dengan jumlah pinhed 39 buah. Secara statistik menunjukan tidak berpengaruh nyata jumlah rata-rata pinhed pada setiap perlakuan, yang ditumbuhkan pada media tanam. Hal ini disebakan penggunaan tepung jagung yang terlalu banyak sehingga menyebabkan inokulum $\mathrm{I}_{2}$ bersifat lengket. Selain itu adanya kandugan aci yang terdapat dalam tepung jagung sehingga pertumbuhan miselia dengan konsentrasi tepung jagung lebih tinggi menyebabkan penyebaran miselianya semakin lambat. Menurut Rasyid (2012), penambahan tepung jagung yang semakin banyak dapat menyebabkan kepadatan 
sehingga penyebaran meselia jamur lebih lambat.

Parameter selanjutnya adalah rata-rata diameter tudung, panjang tangkai dan jumlah tubuh buah jamur. Rata-rata diameter tudung dan panjang tangkai tudung pada perlakuan $I_{3}(50 \%$ serbuk gergaji $+17 \%$ tepung jagung $+33 \%$ bekatul) memperoleh nilai tertinggi yaitu rata-rata diameter tudung $6,4 \mathrm{~cm}$ sedangkan panjang tangkai tubuh buah yaitu 6,25. Hal karena nutrisi yang dibutuhkan untuk jamur tumbuh terpenuhi, baik secara internal maupun eksternal seperti jamur membutuhkan oksigen sebagai pemicu pertumbuhan serta membutuhkan kelembapan yang optimal untuk tumbuh dengan baik. Menurut Suharnowo dkk,(2012), jamur dapat hidup dengan cara menyerap nutrisi dari substrat berupa selulosa, glukosa, lignin, protein serta senyawa karbohidrat. Sedangkan menurut Wartaka (2006), faktor lingkungan yang mempengaruhi pertumbuhan jamur tiram adalah suhu, kelembapan, intensitas cahaya dan sirkulasi udara. Sedangkan pada jumlah tubuh buah jamur tiram pada perlakuan $I_{3}$ tidak memperoleh data yang tinggi hal ini disebabkan karena terjadinya persaingan antara jamur satu dengan jamur yang lainnya yang mempunyai kebutbuhan yang sama untuk memperoleh tempat tumbuh, seperti air, unsur hara, cahaya dan oksigen. Menurut Clapham (1973), jika dua spesies atau lebih terlibat dalam kompetisi secara langsung untuk memperebutkan hal yang sama, salah satu daiantara semuanya lebih efisien dalam memanfaatkan sesuatu yang diperebutkan tadi, maka individu itu akan bertahan hidup, sedang yang tidak dapat memanfaatkan secara efisien yang diperebutkan tadi akan mati.

Untuk pengamatan berat biomassa segar dan berat biomassa kering pada saat panen $I_{3}$ menghasilkan tubuh buah yang lebih berat dibandingkan perlakuan lainnya dengan rata-rata berat biomassa segar 73,5 g sedangkan yang paling terendah terdapat pada perlakuan $\mathrm{I}_{2}$ dengan berat $34,3 \mathrm{gram}$. Sedangkan pada berat buah kering $I_{3}$ yang tertinggi yaitu $23,5 \mathrm{~g}$. Hal ini menunjukkan bahwa pertumbuhan miselium berpengaruh terhadap berat biomassa segar dan berat biomassa kering, pertumbuhan yang baik akan menghasilkan produksi tubuh buah yang baik. Menurut Achmad (2011), penyedian nutrisi yang tersedia sangat bepengaruh pada proses pertumbuhan meselium maupun tubuh buah dalam hal ini semakin kompleks bahan yang digunakan maka semakin banyak nutrisi yang dihasilkan dalam proses pertumbuhan miselium dan tubuh buah. Sedangkan menurut (Parjimo dan Agus, 2007) bahwa pengaruh kondisi lingkungan untuk pertumbuhan jamur berbeda terhadap setiap fase pertumbuhan miselium, fase 
rimordial dan fase pembentukan tubuh buah.

Berdasarkan data yang diperoleh pada perlakuan $I_{3}$ dapat menunjukkan produksi tubuh jamur tiram putih dibandingakan dengan inokulum lainnya. Hal ini sesuai dengan pernyataan Asegab (2011) yang menyatakan bahwa salah satu faktor penentu tinggi rendahnya produksivitas jamur tiram putih adalah dari berat tubuh buahnya.

\section{DAFTAR PUSTAKA}

Achmad. (2011). Panduan Lengkap Jamur. Depok: Penebar Swadaya.

Arief., MS. 2008, Pola Aktivitas Enzim Lignolitik Jamur Tiram Putih (Pleurotus ostreatus) Pada Media Sludge Industri Kertas (skripsi), Program Studi Biokimia Fakultas Matematika dan IImu Pengetahuan Alam Institut Pertanian Bogor.

Asegab, Muad. 2011. Bisnis Pembibitan Jamur Tiram, Jamur Merang dan Jamur Kuping. Jakarta: PT. AgroMedia Pustaka.

Cappucino, J. G. and Sherman, N. (2008). Mikrobiology: A laboratory menual. New York: Pearson.

Cahyana, Y. A. (1999). Jamur tiram. Jakarta: Swadaya

Clapham, W.B. (1973). Natural Ecosystem. Mc. Millan Publishing, Inc, New York.

Corsetti, A. dan Settani, L. (2007). Lactobacilli in sourdough fermentation. Food Research International 40: 539558.

Djarijah. Nunung Marlina dan Abbas Siregar Djarijah. 2001. Jamur Tiram. Yogyakarta. Penerbit Kanisius.
Gunawan dan Wydia, A. (2004). Usaha pembibitan jamur. Jakarta: Penebar Swadaya.

Hendritomo, I. H. (2010). Jamur komsumsi berkhasiat obat. Lily: publishrer.

Iswahyudi, H., Lukmana., M dan Yudha, M. (2017). Limbah sabut kelapa sawit sebagai media tanam alternatif bagi jamur tiram putih (Pleurotus ostreatus). Teknologi Agro-Industri. 4(1), 24074624.

Justo, M. B., Guzman, G. A., Mejia, E. G., Dıaz, C. L. G., Martınez, G., and Corona, E. B. (1999). Calidad protennica de tres cepas mexicanas de setas (Pleurotus ostreatus). Archivos Latinoamericanos de Nutricion. 49(1), 81-85

Kurniawati, I., Luthfianto, D., Noviyanti, R., D. (2017). Karakterisasi Kandungan Zat Gizi Bekatul Pada Berbagai varietas Beras di surakarta.

Lowry, O. H., Rosebrough, N. J., Farr, A. L., and Randall, R.J. (1951). Protein measurement with the Folin Phenol reagent. The jurnal of Biological Chemitery. 193 (1), 265-275.

Maulana, Erie. 2012. Panen Jamur Tiram tiap Musim. Yogyakarta: Lily Publisher.

Maulidina, R., Mudiono, W., E dan Nawawi, M.(2015). Pengaruh umur bibit dan komposisi media tanam terhadap pertumbuhan dan hasil jamur tiram putih (Pleurotus ostreatus). Jurnal produksi tanaman. 8(3), 649-657.

Masyhura, MD.,Nusa, M. I., dan Andriyen, W. (2016). Pengaruh Penambahan Konsentrasi Tepung Tempe dan Lama Perebusan Terhadap Mutu Sosis Nabati dari Jamur Tiram (Pleurotus ostreatus), 20 (1).

Maziero, R., Bononi, V. L., and Capelari, M. (1992). Cultivo e produtividade de Pleurotus ostreatus var. Florida em Mogi das Cruzes, SP, Brasil. Sao Paulo: Hoehnea 
Nurmiati, Pramita I., Periadnadi (2016). Pengaruh Kapur Dolomit Terhadap Pertumbuhan Miselium dan Produksi Jamur Kuping Hitam (Auricularia polythhrica (Mont.) Sacc.). Jurnal Of Natural Science. 4 (3), 329-337.

Parjimo dan Agus. (2007). Budidaya Jamur. Jakarta: Agromedia Pustaka.

Rasyid, A. (2012). Pengaruh Tepung Jagung Terhadap Produktivitas Jamur Tiram Putih (Pleurotus ostreatus). Skripsi universitas Politeknik negerilampung.

Rosmawati. (2013). Isolasi kapang pendegradasi amilum pada ampas sagu (Metroxylon sagoo) secara invitro. Biologi Science dan Education. 3(3), 25-34.

Sagadji, I., Parakkasi, A., Wirayawan, K., G dan Haryato, B. (2008). Perubahan nilai nutrisi ampas sagu selam pada fase pertumbuhan jamur tiram putih (Pleurotus ostreatus) yang berbeda. IImu Ternak. 8(1). 31-34.

Sagala, L. A. B., Aprilina, E., Sonip, A., Risanti, M., \& lan Nawawi, M. (2015). Pengaruh umur bibit dan komposisi media tanam terhadap pertumbuhan dan hasil jamur tiram putih (Pleurotus ostreatus). Jurnal produksi tanaman. 8 (3). 649-657.

Sinaga, S. M. (2011). Budidaya jamur merang. Jakarta: Swadaya.

Soenanto, (2000). Pertumbuhan dan hasil jamur tiram pada berbagai komposisi media tanam. Sekolah tinggi ilmu pertanian amuntasi. 39 (3): 95.

Suarni dan S. Widowati. 2007. Struktur, komposisi, dan nutrisi jagung. Dalam Jagung. Pusat Penelitian Tanaman Pangan, Bogor. hlm. 410-426.

Suharnowo, L.S. Budipramana dan Isnawati. 2012. Pertumbuhan Miselium Dan Produksi Tubuh Buah Jamur Tiram Putih (Pleurotus ostreatus) Dengan Memanfaatkan
Kulit Ari Biji Kedelai Sebagai Campuran pada Media Tanam. Lentera Biologi ( 1): 125-130.

Sumarsih, Sri. 2015. Bisnis Bibit Jamur Tiram. Jakarta: Penebar Swadaya

Suharnowo, Lukas, S., Budipramana., dan Isnawati. (2012). Pertumbuhan Miselium dan Produksi Tubuh Buah Jamur Tiram Putih (Pleurotus Ostreatus) Dengan Memanfaatkan Kulit Ari Biji Kedelai Sebagai Campuran Pada Media Tanam. LenteraBio. 1(3), 125-30.

Sunarmi, Y. I., dan Saprianto, C. (2010). Usaha 6 jenis jamur skala rumah tangga. Jakarta: Swadaya.

Suparti dan Marfuah M. (2015), Produktivitas Jamur Tiram Putih (Pleurotus ostreatus) Pada Media Limbah Sekam Padi dan Daun Pisang Kering Sebagai Media Alternatif. Bioeksperimen. 1 (2), 37-44.

Suriawiria, U. 2002. Budidaya Jamur Tiram. Yoyakarta: Kanisius

Suryani, T dan Carolina, H. (2017). "Pertumbuhan dan Hasil Jamur Tiram Putih Pada Beberapa Bahan Media Pembibitan". Bioeksperimen. 3 (1), 73.

Sutarman (2012). Keragaan dan Produksi Jamur Tiram Putih (Pleurotus ostreatus) Pada Media Serbuk Gergaji dan Ampas Tebu Bersuplemen Dedak dan Tepung Jagung Varibility and Production White Oyster Mushroom (Pleurotus ostreatus) on Sawdust Media and bagasse Supplemented. 12 (3), 163-168.

Swinkels, J.J.M. (1985). Sourch of starch, its chemistry and physics. G.M.A. Van Beynum and J. A. Roels. 1985. Strach Convention Technology. New York: Marcel Dekker.

Wahidah dan Limbongan, A., A. (2015).Pemanfaatan ampas sagu sebagai bahan dasar kompos pada 
bebbrapa dosis pencampuran dengan kotoran sapi.Agricola. 5(1), 1-8.

Wahyuningtyas, D. Purwanto, A dan Fajriyanti, A, N (2014). Pengaruh Jenis Pelarut Terhadap Rendeman Dan Aktivitas Antioksidan Dalam Ekstrak Minyak Bakatul Padi (Rice bran oil). 13(1), 29-34.

Wartaka. (2006). Studi pertumbuhan beberapa isolat jamur tiram (Pleurotus $\mathrm{Sp)}$ pada berbagai media berlignin.
Skripsi. Fakultas kehutanan. Institut Pertanian Bogor (IPB). Bogor.

Wiliams, P. G. (2007). Nutrional composition of red meat. Nutrition and Dietetics. 64 (Suppl 4): S113-S119.

Zadrazil, F., and Kurtzman, R. H. The biology of Pleurotus cultivation in the tropics (1981). In S. T. Chang \& T. H. Quimio (Eds.), Tropical mushrooms (p. 493). Hong Kong: The Chinese University Press, Shatin. 